\title{
Research on the Effect of New media Technology
}

\author{
Maixia Liu \\ ${ }^{1}$ School of the ideological and political theory teaching, Shangluo University \\ a15809148601@139.com
}

Keywords: New media, Ideological and political theory course, Opportunities, Challenge

\begin{abstract}
With the appearing and its rapid developing, the new media played a catalytic role in China's economic and social development, and led to the trend of ideological and cultural pluralism, created a certain impact on the mind of young people. As the party and States' main approaches to promote the theme of propaganda at universities of ideological, the political theory course in the new media environment faced unprecedented opportunities and challenges. Based on the analysis of the opportunities and challenges brought by the new media, the study showed how to utilize the new media technologies in the ideological and political education in colleges and universities, and to provide a certain prove for guiding role of the political theory course teaching, which played on the college students ' ideological education and guiding function.
\end{abstract}

\section{Introduction}

College students are group which are most receptive to the new thing. In the group of using of new media, college student occupy the largest share. Through the new media, they learn the interpersonal communication, publishing information, shopping, entertainment, and so on. In terms of ideological and political theory course teaching in colleges and universities, based on its unique features such as interactive and multimedia, new media widens the education platform and enriches the teaching methods. As we all know, new media is a "double-edged sword", it makes college students study life easier as well as transport the "unfiltered" information to the students, even reactionary remarks and error values intentionally deliberated by Western hostile forces. It produces some certain impact on the ideological and political theory course teaching in the colleges and the under the New media environment, it makes the college ideological and political theory course teaching face both development opportunities and unprecedented challenges.

\section{Opportunities of Developing Ideological and Political Theory Courses in Colleges and Universities under the Environment of new Media}

As engines of development and innovation of science and technology system in China, Universities will not remain indifferent for the emergence of the new media. College teaching, research, management, and service will be associated with the new media. As the main channel of ideological and political education in colleges and universities, ideological and political theory courses in the new media environment also possess a new concept of teaching and good development opportunity.

Expand new channels and space of teaching and enrich the teaching resources. In the traditional ideological and political theory course teaching, the teacher is in a dominant position, is the star of the class. Teachers described the content based on gathered, collated and summarized the written information, Teachers and students in the classroom is in the monotonous pattern-- "student 
listen to teacher". Teachers often cram students with the theoretical indoctrination. On the selection of teaching content, primarily relying on published or issued material such as books, documents as the main reference, Sometimes, existing the phenomenon of unchanged course content out the changing era, it leads to the old teaching content cannot keep up with the pace of the times, resulting in students ' interest is not high. After the emergence of the new media, infinite ways of access widens the information for teachers and students, via the Web, mobile 3G network, student timely access to information of domestic and international hot-button issues for and national policy. The possession of information leads to the teachers and students in the classroom lying on equally interactive relationship. It has undergone enormous changes in the subject-object relation between teachers and students. Expand the classroom teaching methods and channels. It is no longer a traditional teaching mode, but the interaction between teachers and students. In addition to face-to-face teaching methods in the classroom, teachers can also move classes to outside, through opening theme network Web site, BBS or blog, interactive communication space, classes BBS etc, freely communicate with students, breaking the spatial and temporal boundaries, enriching the teaching resources.

Provides modern education methods After the emergence of new media, method and means for ideological and political education in colleges and universities become more diverse. Theory of classroom teaching, in addition to the previously used indoctrination, holding seminars, talking to students, students outside the traditional methods of social practice, can also take advantage of students ' ideological and political education in advanced network technologies. Construction of ideological and political education website through Web communications line, principles and policies of the party and State, highlight the central theme of guiding students to establish a correct Outlook on world, life and values; Open micro blogging, BBS and other ways on campus to provide a networking platform for the exchange of teachers and students, lecturing to reduce face-to-face between teacher and student, persuasion, through a salutary influence of written language to communicate with students by way of mitigation, makes it easy for students to accept. In this modern teaching method, students anywhere, anytime through mobile phones, Internet and other new media education, which greatly improves the efficiency of ideological and political education in the dissemination of information, relieving students psychology phenomenon due to simple preaching[1].

Network new media intelligence provides teachers of ideological and political theory in colleges and universities and the ideological and political educators in a wide variety of education materials and information, Reduces the pressure on teachers, Substitute a lot of repetitive work so that teachers have more time and energy to research of educational theory and education, raising the level of theory and teaching ability of teachers, enhance the relevance and validity of the teaching. At the same time, students can also use the network for outstanding achievements in their own new media quickly spread out, instead of systems, institutions and other restrictions of cumbersome procedures. Visible, the emergence of modern teaching methods, improved students ' learning interest and motivation for ideological and political education theory and practice of a new, unprecedented broad platform.

Reducing teacher-student distance In the teaching process in China, relations between teachers and students more performance management and relationship management. Under the influence of the atmosphere, many students are reluctant to put their mind of telling teachers, teachers and students can't or won't tell the truth to the teacher and say the truth, and lack of trust between teacher and student, this divide between teacher and student influence and constrain the effectiveness of ideological and political education and the quality of emotion education in college 
students ' ideological and political education in the process of obstruction. Emergence of new media has to crack the puzzle. Because of the virtual nature, teachers and students can communicate without meeting, in which breaking the spatial and temporal boundaries of the exchange students can "freely" to speak my mind, to express their views freely inside poured out loneliness, boredom, confusion, etc. Teachers can use the Internet more in-depth understanding of the students ' ideological and, have more real information, so as to grasp the ideological dynamics, "remedy", To organize and guide the discussion in class, relieve psychological pressure on students to solve ideological problems that plague students. So as to narrow the distance between teachers and students, and gradually establish profound friendship between teachers and students, to enhance mutual trust, thus receive an incomparable effect of ideological and political education in General.

\section{Ideological and Political Theory Courses in Colleges and Universities in the new Media Environment facing the Challenge}

New media bring development opportunities to the ideological and political theory courses in colleges and universities at the same time, Also because of its dissemination of information barrier-free nature, features such as interactivity, immediacy lead to all sorts of information dissemination, Contents of which are vulgar and not in line with China's cultural mainstream of thought and speech, With industrialization, commercialization of new media, in order to earn interest, deliberately released some information to improve click-through rate to attract audience attention. Visible, development of new media bring development opportunities to the ideological and political theory course teaching in colleges and universities at the same time, also brought difficulties and challenges [2].

Challenge to teaching ideas. Concept as subjective consciousness always changes with the development of the objective reality and constantly updated. Teaching concept of teachers of ideological and political theory as well. At present, the College ideological and political theory course in the social environment has changed dramatically, with the rapid development of new media in China and the Web application, student access to information more convenient, faster faster. In this case, the dominance of teachers with the information greatly reduced, even through new media such as Internet, students understand the information of speed and scope broader than the teachers. This leads to teachers ' classroom authority considerably weakened, students not interested in teaching and so on. So, face objective environment of change and network new media brings of challenge, College thought political theory class teachers must shift concept, from absolute main of teaching status change for student with for main of interactive exchange, and student swap role that students told teacher listening of teaching way, also can through talks discussion, and speech, and social practice, flexible diverse, and colorful of forms improve students of learning interest, in easily pleasure of environment atmosphere in the to students indoctrination Marx doctrine theory, reached good of teaching effect.

Have an impact on students ' self-control. The emergence of new media provides students with a vast virtual space. They can use the Internet for information, play network games, chatting, watching movies, but can also publish information over the network. This virtual space barrier-free sex and free world Outlook, Outlook on life and values not yet completely formed by college students has brought a lot of temptation. According to statistics, turned on my computer the first thing I used to do when log on QQ. In terms of learning and research, the network can provide students with plenty of references, but it also caused a serious dependency of students. Many students have problems or if you need to write an article, almost no brains, just open the Baidu 
search enter keywords, ready-made answers below. So the student had a severe dependence on networks, and other new media.

Negative impact on students ' moral idea. The new media is a very liberal of virtual space. Here, students can learn about different countries, different national cultures and ideas, understand the gap between Eastern and Western culture, under the influence of a variety of information on the network, they adhere to the moral code and question the culture into a loss situation. Through the network, students can interact with different types of people, speak out with no scruples. Get used to exchange on the network, will appear with the surrounding classmates, teachers and friends gradually alienated, and become cynical, mind-numbing. In addition, the network is also a garbage dump because it contains information about all kinds of sex, violence. Some students lost themselves duo to the influence of the dirty information, and others are addicted to cyber-bullying game, over time became violent and grim, that occur in a real-life ethical misconduct.

\section{References}

[1] Yezhou Li. Study on the effectiveness of ideological and political theory courses in colleges and universities under the network environment. Degree thesis, 2010, Changchun Normal University.(In Chinese)

[2] Zhenxiang Xu. New media: Opportunity and challenge of ideological and political education of college students. Study on the ideological and political education.6(2007)6-12.(In Chinese) 